University of Wollongong

Research Online

Faculty of Arts - Papers (Archive)

Faculty of Arts, Social Sciences \& Humanities

July 2003

\title{
A Shock to the System? The impact of HRM on academic IR in Australia in comparison with USA and UK, 1980-95
}

Diana J. Kelly

University of Wollongong, di@uow.edu.au

Follow this and additional works at: https://ro.uow.edu.au/artspapers

Part of the Arts and Humanities Commons, and the Social and Behavioral Sciences Commons

\section{Recommended Citation}

Kelly, Diana J., A Shock to the System? The impact of HRM on academic IR in Australia in comparison with USA and UK, 1980-95 2003.

https://ro.uow.edu.au/artspapers/25

Research Online is the open access institutional repository for the University of Wollongong. For further information contact the UOW Library: research-pubs@uow.edu.au 


\title{
5:00 PM 7/4/06 1
}

A shock to the system?: The impact of HRM on Academic IR is Australia in comparison with USA and UK, 1980 to 1995

\begin{abstract}
Taking a theme of the transmission of ideas within disciplines, this paper investigates the impact of academic human resource management on academic industrial relations, comparing the impact in Australia between 1990 and 1995 with the earlier responses in UK and USA. It is shown that while HRM had a significant effect on academic industrial relations, the extent of that impact is not wholly clear because other events, such as public policy shifts and the changing role of universities also affected academic industrial relations.
\end{abstract}

Diana Kelly

University of Wollongong 


\title{
5:00 PM 7/4/06 2
}

A shock to the system?: The impact of HRM on Academic IR is Australia in comparison with USA and UK, 1980 to 1995

\begin{abstract}
Taking a theme of the transmission of ideas within disciplines, this paper investigates the impact of academic human resource management on academic industrial relations, comparing the impact in Australia with the earlier responses in UK and USA. It is shown that HRM did have a significant effect on academic industrial relations, but the extent of that impact is not wholly clear because other events, such as public policy shifts and the changing role of universities also affected academic industrial relations
\end{abstract}

\section{Introduction}

Any analysis of disciplinary history is an investigation of the transmission of ideas - how ideas are taken up or rejected. This is because, as coherent bodies of ideas, disciplines cannot be static. As will be evident in the analysis below, this was especially the case in the late twentieth century, when the social sciences were subject to continuing pressures for changes in emphasis, direction or even more fundamental structural shifts. The capacity and nature of shifts in a discipline will depend on the discipline and its community of scholars, but whatever the approach, the notion of dynamism is essential to any analysis. Understanding the nature of this intellectual perpetual motion can enhance our knowledge of the transfer of ideas. Moreover, in asking what ideas are taken up by scholars in a discipline and what ideas are rejected can clarify our understanding of the disciplines.

From its arrival in the 1980s, for example, Human Resource Management (HRM) took over much of the intellectual territory formerly held by the field of industrial relations. With antecedents in human relations approach to management, but with the signs and spin of the late twentieth century, human resource management catapulted to the centre in the enterprise and the academy, taking many of the former industrial relations scholars with it. 


\section{5:00 PM 7/4/06 3}

The focus of this paper is on the effect of HRM on academic IR in Australia, in comparison with that of USA and UK. In all three countries HRM appeared to arise, albeit at different times, as a fully formed and assured body of persuasive ideas far more plausible to scholars and employment practitioners than the older and more ambivalent IR. In the paper it is argued that the different responses to HRM reflected particular historical and environmental aspects in these Anglo-phone countries as well as the different attributes of the scholarly community.

\section{Australian academic IR in the 1980s}

By the latter 1980s, forty years after it was first taught in universities, industrial relations was a recognised undergraduate and postgraduate specialisation across Australia at most old universities and at many of the former Colleges of Advanced Education (CAEs) as well. To a fair degree there was consensus over the subject matter, which, by contrast to the earlier decades, tended toward an institutional focus with most interest in trade unions, employer associations and the State and State agencies such as the conciliation and arbitration systems. It was not that management was overtly excluded, but rather the institutions were deemed more important for investigating the interactions and processes of rulemaking over wages and conditions.

Within the mainstream of industrial relations there were, of course, intense debates over priorities policies and practices relating to these issues, yet there was also a fair degree of acceptance of the mainstream of industrial relations, even by those who stood outside it. It was an object-oriented discipline, with investigation focused on particular objects of analysis rather than on theory development, with scholars drawing heavily, as they had always done, on methods and techniques from many disciplines. The multiple changes to work and employment that took place in the Accord years gave these object oriented scholars many opportunities for broadening their research and teaching well beyond the narrower confines of the mainstream. The absence of an overarching theory was a continuing source of self doubt, yet relative to earlier years, there was by the end of the 1980s, a fair degree of self-assuredness that industrial relations had proven itself to be a legitimate and rigorous academic discipline with its own 'territory'.

However, the self-assuredness of industrial relations scholars was premature. The changes in public policy, labour market structures, business agenda and management 


\section{5:00 PM 7/4/06 4}

methods also became evident in the higher education sector, where business methods of administration became a requirement in the 1990s. "New" language such as customerfocus, measurable outcomes and key competencies entered university vocabularies, as did performance appraisals and point systems for publications for academics. Whereas professional and vocational education had previously been barely tolerated (aside from the prestige professions and vocations), the structure of university education had by the 1990s become vocationally oriented, thus giving higher priority to employers' interests. (Karmel, 1990)

These new demands on academics also encouraged an element of short termism and fragmentation in research. The North American model of large teams of researchers and subdivided research labour met with considerable encouragement through the Australian Research Council (ARC), while the publication measurements systems appeared to encourage quantity, rather than quality, of output. (Falk, 1990) For industrial relations researchers, the new pressures reinforced the tendency toward object-oriented and short term research over theoretical and analytical development.

\section{The sharp shock of 1990}

Despite early warnings, ${ }^{1}$ and perhaps bolstered by the sustained acceptance of the Accord process, industrial relations academics appeared to have paid little heed to the spectre of HRM apparent overseas. The first broad recognition of the threat of HRM in Australia came at what was then the discipline's major academic conference, the Association of Industrial Relations Academics of Australia and New Zealand (AIRAANZ) Conference in July 1990. Held 18 months after the previous conference, the Melbourne conference was attended by the largest number of participants up to that time. ${ }^{2}$ Of the 31 papers presented at the Melbourne conference, seven presentations papers focussed on aspects of employment management, notably Boxall and Dowling (1990), Howard (1990), Bamber, Howell and Shadur (1990), and Sutcliffe and Sappey, (1990), as well as Taylor's paper on management education (Taylor, 1990) and Palmer's Presidential Address which was given on the Opening night of the Conference. (Palmer, 1990) While the Presidential Address was given at a social function attended by all the registrants, there was also standing room only at the other papers, despite parallel sessions.

Authors of at least two of the presentations (Palmer, 1990; Boxall and Dowling, 1990) emphasised HRM as a general advance in the control and administration of the employment relationship, as study and as a 'real world activity'. This raises the 


\section{5:00 PM 7/4/06 5}

difficult question of the links between the rhetoric or idealism in personnel management / HRM, and the apparent industrial relations approach to the relationship between employers and employees which had tended toward 'realism'. For analysts such as Laffer $(1968,1971,1974)$ and Niland, (1981, 1984; see also Niland and Prothero, 1976), for example, the study of industrial relations rested on concerns over the regulation of work and the outcomes for employees and business. While the analysis of these latter authors hinged on the 'labour problem', other principles such as equity and the moral order were not excluded from their research.

By contrast for Boxall and Dowling, the needs of business had paramount significance. This meant that factors which did not 'fit' the ideal were eliminated from consideration. It is not that such an approach should be subject to judgment, per se, but rather that any analysis of such an approach needs to take account of the fact that HRM was founded, and remained thoroughly grounded, in managerialist principles. For writers such as Boxall and Dowling (1990) therefore, the primary object of analysis was the employment relationship, just as it was in industrial relations, but the primary objective was to give top priority to the needs of enterprise, in which the employees were instrumental, rather than the focal point. There was thus a strongly normative element in the writings of analysts such as Boxall and Dowling, for whom the imperative of HRM, as study or practice is to obtain best outcomes for business.

At the Melbourne AIRAANZ Conference of 1990, the response to the Presidential Address and the "HRM" papers was one of dismay, disbelief, and deep concern. Scholars rejected the foundations of HRM, the suggestions to integrate with HRM, and even notions that the emergent field of study should even be taken seriously. Debate followed on debate, with some scholars doubtful of the intellectual elements, others at the ideologically driven elements. Several scholars pointed to the frequent conflation of 'theory' and practice' in HRM while many drew on notions of academic freedom and intellectual integrity, which had also been raised by Taylor in his paper on management education. (Taylor, 1990) Concerns were not so much with the 'practice' of HRM - the ways in which employers "manufactured consent", had been a common area of teaching, if not of research in Australia since the mid-1970s. Rather most indignation was reserved for the notion that the exponents of HRM were not simply claiming superiority of business practice, but superiority of HRM as intellectual craft. 


\section{5:00 PM 7/4/06 6}

Certainly, the HRM scholars drew on a different epistemology. Palmer (1990, p.3) highlighted the superiority of HRM by reference to the "sophisticated techniques of organisational change at QUT" as an example of the superiority of HRM. Similarly, Boxall and Dowling had appealed to the enterprise focus and advantages for competitiveness from HRM. For these analysts the logic of HRM as an academic discipline lay in its success with the business community and its legitimation from business. It is not surprising then that Boxall and Dowling could assume the ascendancy of HRM, so that the sound and fury in the debates was indeed clear evidence of the claims of superiority by the HRM academics, and

HRM would hardly have aroused the interest and passion it has unless it did represent something of a discontinuity. (Boxall and Dowling 1990)

For the industrial relations scholars such self-assured claims of HRM scholars had a certain irony to them. Having achieved a fragile status as an academic discipline, ${ }^{3}$ it appeared to the AIRAANZ members at that 1990 conference and beyond, that their disciplinary status was again under threat even from within. Moreover the 'threat' came from an area of study which appeared to have a fundamental normative bias and to have attained the same academic status with extraordinarily rapid success.

\section{Responses to HRM}

In the face of what they perceived to be a major attack on their craft, most industrial relations scholars responded and reacted immediately and over the next few years in several definable ways. Such responses were mediated by the continuing research commitments, the shifting sands of public policy and legislation, and the increasing pressures on higher education to become 'customer-focused'. In this respect the continuing change in universities was an important fillip for HRM, but it also blurs the effect of HRM on industrial relations scholarship. With increasing importance given to professional and vocational education for domestic and international students, the higher education sector was increasingly driven by career interests of students and employer interests in business focused education. And, in an environment where major workforce reductions had been occurring for nearly a decade, and flexible employment structures were burgeoning, new forms of management practice were an obvious start. Hence, there was increasing demand for 


\section{5:00 PM 7/4/06 7}

business focused education which trained students in the new forms of management practice.

Before examining the responses of the Australian industrial relations scholars to these kinds of pressures, those of their USA and UK counterparts offer some useful insights into the nature of the debates.

\section{US Responses to HRM}

In the US the early responses to HRM attempted to integrate the two 'schools' of IR and HRM. Indeed 'labor relations' scholars had been involved in the seminal Harvard HRM model of Beer et al. (1984) Among the industrial relations specialists of the later 1980s, two responses became apparent. First, an linking framework was proposed in which the two schools would develop in tandem, mirroring the structure of many academic units. This would have the advantage of improving organisational security for the professional association, Industrial Relations Research Association, (IRRA), in which membership was declining, reflecting the shrinking place of industrial relations in the USA. ${ }^{4}$

Historically, American scholars perceived industrial relations as dealing "with employees organized by trade unions", whereas by contrast "... human resource specialists ... dealt with nonunionized personnel". (Meltz, 1992, p.255). The union focus of the American scholars had increased from the 1960s, which Kaufman claimed had derived from the ejection of personnel management scholars in the 1950s, (Kaufman, 1992, 1993) and became fixed from the time of Dunlop's (1958) Industrial Relations Systems (see also Dunlop, 1993). While Kaufman perhaps overstates his case, there is no doubt that much of the industrial relations scholarship attempted to shadow economics and to focus more on the unionised sectors. Certainly by the early 1990s the US scholars felt a "palpable sense that the field is in danger of marginalization", (Kaufman, 1992, p.263) and were searching for any means to regain a place at the centre.

Given these perceptions and the rapid incursion of the new field of HRM into the intellectual 'territory' of industrial relations, it is perhaps not surprising that scholars began demeaning industrial relations, particularly its purported tendency to promote adversarialism. ${ }^{5}$ (McKersie, 1990, pp.4-5) Scholars began to de-emphasise the role of trade unions as promoting labour, and to re-emphasise collective bargaining as "cooperation of greater power-sharing". For Kaufman, the historical emphasis on 


\section{5:00 PM 7/4/06 8}

unions and collective bargaining had been the major weakness of industrial relations analysis, and one that had been unjustified, given the improved quality of employment. This major historian of industrial relations in the United States (Kaufman, 1993) argued that the decline of academic industrial relations reflected a shift away from attention to trade unions, a shift that was well overdue not only for disciplinary security, but because

Over the last half century ... most of the causes of labor's disadvantageous position have been significantly reduced ... fewer workers suffer from a disadvantage in bargaining power and the extent of this disadvantage is likewise smaller. As a result the playing field is more level, thereby reducing the demand for collective bargaining by organized workers. (Kaufman 1993, p.172)

Moreover, asserted Kaufman, trade unions and collective bargaining processes were potentially deleterious insofar as

... once a union is recognized, its exercise of bargaining power will lead over time to monopolistic wage premiums and attendant forms of misallocation. [furthermore] A particularly salient issue in judging the continued efficacy of collective bargaining is whether the adversarial principle on which the [collective bargaining] system is built is still compatible with the attainment of world class standards in product quality and productivity. The newest generation of best practice plants, for example, rely heavily on trust-building, employee involvement and flexible work rules, attributes that seem considerably more difficult to initiate and maintain successfully in unionized situations. (Kaufman 1993, p.172-3)6

For scholars like Kaufman therefore, the 'new' industrial relations, as modified by the transforming character of HRM and the international economic environment, was unproblematic, particularly given the imperative for improving the competitiveness of American firms. In this respect scholars like Kaufman could readily accept the language and objectives of HRM as a means to competitiveness, for competitiveness was central to business and national success.

The central claim of HRM, as practice and for its scholarly promoters, lay in its capacity to "achieve competitive advantage for the firm". The weaknesses and elisions in theory and practice were admitted but only as challenges. As Lewin, Mitchell and Sherer (1992) noted 


\section{5:00 PM 7/4/06 9}

While scholars may discount [HRM] writings for their lack of scientific underpinnings, they nevertheless reflected the influence of new competitive forces, stemming largely from international sources and deregulation .... on utilization, assessment and motivation of employees ... Hence the short-term quick fix orientation to personnel management appeared ... to give way to longer-term strategically driven human resource management policies and practices (Lewin, Mitchell and Sherer, 1992, 606)

In accepting the language and logic of the HRM analysts, scholars in the USA therefore altered their emphases toward the employment relationship, but the shift was not so much transformational for some as a turn in direction. Even scholars who acknowledged inequality in the employment relationship, and saw the concomitant need for trade unions, were sanguine about segueing into a managerialist conception of employment. (Kochan et al., 1994)

Others attempted to develop upon managerialism by inserting unionism into the model, such as the MIT IR/HRM Study (Kitay and Lansbury, 1997) or Kochan and Osterman's (1994) Mutual Gains Enterprise. The plans to integrate or reintegrate industrial relations were not simply for organisational security of a learned and professional association. Scholars such as Kochan, Osterman and Capelli (see e.g. Kochan and Osterman, 1994) were seeking ways of maintaining or introducing a union-positive perspective in employment relations. This was as much an altruistic view, as a determination not to waste their human capital. For example, in Kochan, Katz and McKersie (1986) and Kochan and Osterman (1994) it was possible to demonstrate the positive affects of union-management cooperation on the competitiveness of businesses.

The difficulty with this approach as became evident in the IRRA literature was that instead of civilising HRM, industrial relations would absorb the language and the objectives of HRM. The objective of Kochan and Osterman's Mutual Gains Enterprise was to purvey a pro-union business-oriented perspective on management at the enterprise, but to do this, they necessarily resorted to the terminology and imperatives common to HRM prescriptions. Thus within a decade of the seminal but widely feted proclamation of HRM (Beer et al., 1984) scholars had embraced HRM, albeit with concerns over the deunionising objective of many American HRM initiatives. (Kochan et al., 1986, Chelius and Dworkin, 1990)**add more here to reflect latter 1990s) $* * *$ 
Responses to HRM in the UK

Responses to HRM by many UK scholars were rather less accommodating, although there were serious attempts to investigate, describe, and categorise varieties of HRM (Storey 1991; Blyton and Turner, 1992; Keenoy 1990). Some scholars undertook to promote HRM as a positive phenomenon, and journals like the International Journal of Human Resource Management appeared from 1990. From an Australian perspective one of the most notable proponents of HRM was David Guest (1987) who, like his counterparts in the USA, drew on the implicit jingoism in which HRM was portrayed as essential for the national economy.

British industry still lags far behind its main competitors. For further catching up to occur, it seems likely that a fuller use of human resources will be necessary. This is likely to require a shift in emphasis away from industrial relations systems toward HRM policies as the main path to improved performance. (Guest, 1991, p.58 (see also Torrington, McKay, and Hall, 1985))

Guest's careful scholarship was not uncritical. Indeed, like many of the British scholars, Guest took an interpretative approach to HRM. In examining the reasons for its success in the US, for example, he noted the parallels between the language and normative values of HRM and the resurgence of the 'American dream' following the election of Ronald Reagan. (Guest, 1990) HRM, appealed to the frontier mentality said to be deep in the national American psyche. The message of HRM enhanced the ideals of individual self improvement, human growth and opportunities for progress. It was important for managers too, asserted Guest, because they were portrayed as purveyors of progress and self actualisation, Moreover, HRM appealed to the 'American Dream' because it required strong men and great leaders in the traditions of great American leaders. (Guest, 1990, see also Guest, 1987, 1991) What is important about Guest's interpretative approach is that he was not critical of notions of HRM per se, and indeed is generally cited as one of the phenomenon's chief promoters in the UK. Rather, Guest's approach reflects the response of many British scholars to HRM. This was the evolution of a whole new subfield of critical management. (see e.g. du Gay and Salaman, 1992, Sewell and Wilkinson, 1992, Delbridge, Turnbull and Wilkinson, 1992, Keenoy and Anthony, 1992). Legge, (1995) for example, argued with only slight irony, that academics became primary 


\section{5:00 PM 7/4/06 11}

stakeholders in the transactions of HRM, not only marketing their intellectual legitimacy and expertise to business, but also

Nostalgia for discipline origins, not to mention the labour process heyday of the 1970s and early 1980s, made some academics more prone to see HRM ... as a mediator of the contradictions of capitalism, rather than the key to competitive advantage, Additionally academic careers can be forwarded by a critical dissection ... of new orthodoxies. Hence a large critical literature has emerged that has focused on deconstructing the contradictions and rhetoric of HRM. .... [E]ven the most passing acquaintanceship with actor network theory would suggest, successful academics have to develop an entrepreneur's sensitivity to consumer taste and market niches. (Legge, 1995, pp.49-50 See also Anthony, 1986)

In other words, Legge argues that the critical management academics, including herself, gained the paradoxical opportunity for critical scholarship, while at the same time ensuring job satisfaction and security. It is important to note, however, that there was a lag. While the critical management school of thought has continued to bloom, and indeed developed further subfields such as organisational discourse, (see e.g. Keenoy et al., 1997) the mass of publications only became apparent in the 1990s, over a decade after Margaret Thatcher came to power. We will return to this lag later. For now, it is worth noting that for various reasons, one outcome of the arrival of HRM for industrial relations scholarship was the emergence of a counter-field of critical management. ${ }^{7}$

Not all scholars took up HRM from a positive or critical perspective. The British Journal of Industrial Relations remained what is arguably the most prestigious English language journal in the discipline, and continued to publish an eclectic array of material under the general label of industrial relations. ${ }^{8}$ This was in large part because of the tradition of workplace analysis in British industrial relations which had followed the business and government concerns over the workplace in Britain. As the Donovan Commission in the 1960s had emphasised, there had always been an enterprise focus in UK industrial relations practice and scholarship. Moreover, the higher education system in Britain, together with the traditions of case study research, had meant that the commitment to holistic industrial relations scholarship had been long apparent in the UK. In this respect it is not surprising that the academic debates included methodological debates, (Marginson, 1987), aspects of epistemology (Keenoy, 1991; Dunn, 1990) and research into personnel and human resource 
management (Guest, 1991) The continuing role of BUIRA and publication of new editions of basic texts all attest to the continuing role for industrial relations research and teaching, particularly at the large schools which had developed at Cardiff and Warwick. ${ }^{9}$ While the focus of research was on 'traditional' issues of job regulation, the role of managers as the business activists had re-entered as central players. (e.g. Hyman and Ferner, 1994; Blyton and Turnbull, 1992) In summary the responses of British industrial relations academics to the emergent and ascendant HRM were strategic, with rather less breast-beating than in the USA.

\section{Responses to HRM in Australia}

Given the links between scholars in Australia, the USA and the UK, the 1990 AIRAANZ Congress is perhaps an artificial date for HRM to burst on the scene. This is particularly so if the forewarnings of those such as Plowman (1989) and Haworth (1989) are taken into account. Moreover, as has been shown, despite the much earlier decline in unionism in the northern Anglophone countries, together with the strident anti-union, and pro-business rhetoric and regulation of the Thatcher and Reagan governments, academic publications which indicated respondent shifts in research direction took several years in those countries. Nevertheless, and perhaps as a consequence of the events and imperatives in the UK and USA, Australian scholars in IR responded quite quickly to the claims of the 'foreign conquerors'. The responses in Australia reflected elements of both the USA and UK responses.

Some scholars' research was seemingly unaffected by the claims of HRM, (see e.g. Dabscheck, 1995) ${ }^{10}$ but in general industrial relations academics appeared to take heed of the challenge to their discipline. Two other specific responses are apparent. The first was a broadening of the industrial relations mainstream, as Vic Taylor (1990) had proposed at the 1990 Melbourne AIRAANZ Conference, while the second was an initiative to integrate 1980s type mainstream industrial relations and HRM. These can be designated Broad $I R$ and $H R M+I R$ respectively. While there were some similarities in both responses, there are also significant differences, for example in the definitions each of these two strands ascribes to industrial relations and the trajectories that each was taking through to the mid-1990s which is the end of this study.

Broad IR was characterised by a continued expansion of the objects of study, and by sustained acknowledgment of the complexity of factors which influenced those 


\section{5:00 PM 7/4/06 13}

objects of study. What differentiated it from the arbitration-focused approach of the 1980s mainstream was that the formal public system shifted from the centre of study to that of an (occasionally) intervening variable. In its place, the centre of study were work and employment relationships at a macro or micro level. The organisation of employment relationships globally, nationally or at the enterprise was assumed to influence and in turn be influenced by production and market outcomes.

Within this enhanced expanded approach were a variety of analytical frameworks, drawing on scholarship not only from the USA and UK, but also from Europe and Japan. Much of the international research took management practices as a primary influence on work and production, just as some scholars had been propounding for some years (Taylor, 1989; Lansbury, (Lansbury, 1978, Lansbury and Spillane, 1983; Plowman, 1989). Some scholars for example followed the British critical management analyses, and examined management initiatives such as Total Quality Management or Best Practice with a scholarly rather than policy intent. (Kelly, 1995; Baird, 1994, Rosser, 1992; Rosser, Todd and Fells, 1995) The work of Kochan and others (see Kochan et al. 1986; Kochan and Piore, 1990) in developing an international framework for comparative analysis brought American models of Broad $I R$ into consideration. These not only extended the older areas of study well beyond formal rulemaking process, but also attempted to go to go beyond the constraints of labour problem. (Lansbury and Bamber, 1995; Kelly and Underhill, 1995; Kitay and Lansbury, 1997) The influences on Australian scholarship broadened considerably to include Japanese management styles and strategies, German production methods and enterprise organisation, and notions of completely relations of production arising from changing methods and imperatives of production. ${ }^{11}$ Terms such as lean production, flexible specialisation and post-Fordism had all entered the vocabulary of academic industrial relations research and teaching.

By contrast, other scholars focused on the changes in public policy from award restructuring to enterprise bargaining which had firmly placed the needs of industry and enterprise as a top priority. (Junor, Barlow and Paterson; 1994; Gahan, 1993) . Yet in investigating even these 'traditional issues, the attention had shifted toward the links between employment, production and market factors. The processes of regulation of employment were still of central significance, but more tightly bound to the context. The importance of all of these scholarly initiatives for industrial relations scholarship in the Broad IR model, was that in many respects it offered a reemphasis on the need for integrating complex factors which involved work and 


\section{5:00 PM 7/4/06 14}

employment. At issue was not the 'labour problem' but a production problem, and as the expanding array of forms of organising production and work became apparent, the multiple determinants were analysed in light of the effects that regulation and organisation of work and employees may have on production.

Because the complexity was taken as a given, scholars tended to pay closer attention to analytical rigour, as the increased breadth of methods attest. In one way, the scholars taking a Broad IR approach industrial relations scholars had moved away from a disciplinary cringe to a renewed awareness that multidisciplinary research for complex phenomena like industrial relations is good research practice. At AIRAANZ conferences in the early 1990s scholars used econometric and statistical techniques, case studies, and hermeneutics, while often employing at the same time a range of theoretical management and political science models or critical legal studies. (see e.g. Nyland and Svensen, 1994; Fox and Teicher, 1994)

\section{The HRM+IR response}

By contrast the $H R M+I R$ response to the incursions of human resource management tended to be much more focused. At the 1992 AIRAANZ Conference Gardner and Palmer proposed the formation of a new field of study which integrated HRM and IR. Their model first encapsulated IR as mainly covering collective institutional forms of conflict resolution, since "industrial relations assumes diverse and conflicting interests between management and worker, and is concerned with mechanisms to give voice to those differences" (Gardner and Palmer, 1992a, pp.109-13, 119) Drawing on the often conflicting interpretations of the proponents of HRM (Torrington and Guest, 1990) and the British critical management theorists, (Legge, 1991), Gardner and Palmer were less specific about human resource management. However, recognising the diffuse nature of HRM, they argued that "human resource management is more concerned with the enterprise and the effective enhancement and deployment of the skills of individuals within it". (Gardner and Palmer, 1992a, pp.113-9) Taking the two concepts, IR and HRM, as objects found within organisations, Gardner and Palmer then developed a means by which the two areas could be linked. Given the complexities of modern organisations, argued Gardner and Palmer (1992a, pp.109-30), the link between industrial relations and HRM is to be found in the availability of strategy, implicit or purposive, to all of the parties 


\section{5:00 PM 7/4/06 15}

within an organisation. Thus strategy builds on the commonalities between industrial relations and human resource management, because

in those strategies - if not in the academic discourse - [organisations] find some way to meld industrial relations and human resource management. Not all succeed, but where they do they point to a viable integration of employment relations.(Gardner and Palmer, 1992a, p.128) 12

The bridge between these two vastly differing disciplines is strategic choice theory which had been popularised by Kochan et al. and was also a basis some of the Broad $I R$ approaches in the 1990s. ${ }^{13}$

The need to promulgate the $H R M+I R$ perspective was in large part the basis of the formation of the International Employment Relations Association (IERA) in 1993, in which year a major new journal, The International Journal of Employment Studies also commenced. Both initiatives occurred under the aegis of the Department of Employment Relations at the University of Western Sydney, whose senior academics had been propounding an $H R M+I R$ perspective in their research and teaching since the late 1980s. (Hayward and Mortimer, 1988)

A primary objective of IERA was to develop employment relations,

both in terms of theory and in terms of practice and a desire to see the field as a living one not just as academic discourse but also to encourage debate with practitioners as to the relevance of this concept [employment relations] in practice. (Mortimer and Leece, 1994a, p.3)

Thus, membership of IERA was rather more broadly based than AIRAANZ, with membership open to practitioners and academics alike. Like AIRAANZ, the focal points for IERA were its annual conferences, at which practitioners were invited to present papers. Between ten and twenty per cent of papers were presented by HRM managers or consultants. The great majority of papers however, were presented by academics. (Mortimer and Leece, 1994a 1994b, 1994c; Pullin and Fastenau, 1995; Dundas and Woldring, 1998)

For the IERA scholars, the $H R M+I R$ conceptualisation of employment relations ${ }^{14}$ signified both a basis for study and for practice beyond the scholars' interpretations of industrial relations. While this led to a degree of reification, the research at IERA Conferences generally sought test and realise advantages of HRM+IR approach. As Fastenau and Pullin argued, 


\section{5:00 PM 7/4/06 16}

While IR is concerned with collective efforts and responses HRM is concerned with individuals - individual employees and individual organizations. While the IR perspective focuses on workers' efforts to control the employment relationship and employer response, HRM focuses on management efforts to direct and control the employment relationship ... The fundamental difference between Employment Relations and its contributing concepts of IR and HRM is that Employment Relations recognizes the conceptual and practical insights which result from studying employment relationships explicitly addressing the dynamic exchange between the internal environment of organizations and the external context in which they operate. (Fastenau and Pullin, , 1995, p.208)

For these scholars then, employment relations drew on an $H R M+I R$ blend which rested on the fact that industrial relations was characterised by 'worker focus' and adversarialism collectivities". (see e.g. Leece, 1995). In seeking to direct the scholarship of their strand or school toward a combined but different paradigm, the leaders of the employment relations followed from the earlier prescriptions of Boxall and Dowling at the 1990 AIRAANZ Conference. The HRM+IR employment relations proponents first distilled the concepts of both HRM and industrial relations, and then sought recombination which would absorb aspects of both disciplines, as defined. They also sought a strong practical and prescriptive intent in scholarship, which would realise the academic concept in the 'real world'.

There was clear evidence of the success of the $H R M+I R$ conceptualisation of employment relations in the early and mid 1990s. Gardner and Palmer's text provided a comprehensive text which covered aspects of both industrial relations and HRM as described above. Chapters on trade unions, employer associations and tribunals were balanced with chapters on staffing policies, management history and training. Together with other texts (see e.g., Mortimer and Leece 1995) the HRM+IR approach proved useful in teaching programmes, particularly in areas of business studies. (Griffith University, 1995)

Certainly there was pressure from universities and employers for a more focussed business oriented approach. By the mid-1990s, declining unionism and an increasingly self-assured business lobby were demanding business graduates wellversed in the business discourse. Industrial relations, had been portrayed by business lobbies such as the Business Council of Australia as being an essentially adversarial concept, inappropriate to modern business practice, a portrayal which business schools and programmes appeared to accept. (Hilmer et al. 1989, 1991, 1993) 


\section{5:00 PM 7/4/06 17}

Moreover, universities were under increasing pressure to provide professional education and employment skills above all else, while the rising importance was given to measuring teaching success by a simple measure of student numbers. In light of these pressures it was not surprising that many universities were reducing or repackaging their industrial relations programmes in order attract students and appear to convey familiarity with business discourse. In this respect, the HRM+IR employment relations approach proved a marketing success.

The picture was however, more complicated. Many industrial relations academics who come under the rubric of Broad IR, were also beginning to use the term 'employment relations', as a means of relabelling but not repackaging their discipline. (see footnote 28) Such an approach was not new. Even in the 1980s scholars such as Kitay and Sutcliffe, had used the term interchangeably with industrial relations. By the mid 1990s for many scholars the term 'employment relations' did not reflect a particular paradigmatic approach, but rather an substitutable term for industrial relations, with less of the negative baggage purveyed by the business lobbyists.

Moreover, despite the directed attempts of the $H R M+I R$ employment relations scholars to define their school as a sharp break from tradition, there were clear similarities between Broad $I R$ and $H R M+I R$ approaches. As Fastenau and Pullin (1995) had noted (see above), analysis could cover a great range of material, at macro and micro levels, in which macro and micro contexts were integrated. Thus in many respects the differentiation between the two approaches was more designated than real by the mid 1990s. The perception of similarities was also apparent in the overlap papers which were presented at IERA and AIRAANZ between 1993 and 1995). ${ }^{15}$ From the perspective of the leaders of the $H R M+I R$ school, the difference lay in the perceptions of what constituted the study and practice of industrial relations, the tendency to conflate the intellectual domain with the activities of practitioners, and the high regard given to human resource management. This differentiation may be increasingly difficult to impose as trade unionism continues to decline and the formal public industrial relations is shifted to the 'private sphere' of individual contracts. 


\section{Was HRM a Shock' to the System?}

This investigation of academic industrial relations in the last decades of the twentieth century has been a history of shifting ideas. In the 1980s industrial relations appeared to have matured, and become a self-sustaining field of study with an increasingly confident air, albeit with clearly different strengths in the discipline in each of the Anglophone countries. It was in taking account of the strengthening discipline of IR, that this paper began with the question of the extent to which HRM has influenced the nature and direction of scholarship and teaching since the advent of HRM. Certainly there were evident reactions and countervailing responses, and certainly by the mid-1990s and later, academic industrial relations bore different features and approaches to the earlier images.

In the USA the response was relatively tardy. ${ }^{16}$ The 'transformation literature' (Kochan et al 1986) began towards the end of Reagan era, and Kochan and Osterman's (1994) Mutual Gains was well over a decade after Reagan commenced serious State de-legitimation of unions. The slowness of US responses was particularly notable insofar as more than UK or Australia, academic analysis in US had focused most heavily on labour markets, trade unions and collective bargaining. For the North American academics, the assault on collectivism appeared to cut at the heart of their discipline. Yet, despite some rumblings, (Kochan and Barocci, 1985) the American academics were relatively tardy to respond to their challenge, and indeed appeared to have changed rather less than their counterparts in UK and Australia. On the other hand given their long acceptance of the more classical aspects of institutional economics and of neoclassical economics (Kerr, 1994), the acceptance of HRM-as-practice was not difficult for many. (Kaufman, 1993; Stern, 1992). Yet pro-collectivist social democrat scholars like Kochan expressed clearly articulated concerns at the ideological implications of HRM, and attempted to integrate notions of industrial relations within the HRM paradigm.

By contrast, many of the British scholars remained either avowedly 'pluralist' in the sociological sense; others attacked the heart of HRM, by making use of the broader academic training received in the UK, and drawing upon clever analysis and multiple disciplinary weapons to question HRM through a critical approach. For many industrial relations researchers, the way of dealing with the 'foreign conquerors' of HRM was to attack the logic and underpinnings of HRM. 
And to the industrial relations academics they were 'foreign conquerors', insofar as the proponents of HRM sought to diminish the role of industrial relations and replace it with a new and more certain mode of practising and researching the employment relationship. Where the academic study of industrial relations had promoted, albeit mostly implicitly, notions of civilising capitalism through promotion of stability, fairness, and consistency the proponents of HRM appeared to the scholars in industrial relations as foreign conquerors with different priorities and different notions of legitimacy, intellectual adequacy, and relevance.

Thus in Australia, the arrival of HRM fully formed, certain and intent on marginalising alternative modes of analysis appeared to 'shock' the academics at AIRAANZ 1990. But, (perhaps not surprisingly for such an object-oriented discipline), changes in scholars' methods and analysis had already begun as they began to investigate and analyse award restructuring, second tier bargaining and the production focus of the ACTU in the 1980s. In much of this analysis, researchers familiar with the case study method, or the older scholars drawing on the analytical framework of the Oxford school or the labour process literature, had little difficulty in the downward shift in focus.

There is also no doubt that the attempts to achieve legitimacy with the academic economists, the need to be relevant to policy makers and practitioners, or to deal with current issues, together with the economic policy focus of senior scholars like Isaac and Niland, (see e.g. Isaac, 1985; Niland, 1981, 1984) had all led to considerable attention from the late 1970 s to the late 1980 s to the macro and institutional systems. As well the changing government economic policies in the same era, the increasing focus on the problems of inflation and unemployment, (with both of the latter seen as problems from a range of ideological perspectives) had reduced the attention to micro issues for a time in the early 1980s. However, the attacks of the New Right on what had appeared to be core elements of social democrat ideology, and the failure of macroeconomic policies to increase labour productivity inter alia, led to closer focus on the workplace, and enterprise. Such a downward shift necessarily redirected industrial relations scholars' attention to the roles and styles of management, particularly given their traditional tendency to follow public policy. National surveys such as AWIRS-1, and later the long-planned national committee of inquiry in to management (Karpin Report, 1995) attest to the increasing attention to workplace issues which occurred alongside the rise and rise of HRM 
There is no doubt that HRM constituted a major challenge to Australian academic industrial relations and that the academics were shocked for a year or two from 1990. The HRM model had been slow to influence academics in Australia prior to the 1990s because so much of the 1980s had been taken up with consensual aspects of the Accords, and the frequent policy shifts. In part HRM represented a structural change since the new field of study was incorporated into business education. The latter was the area of greatest growth in higher education just at the time that managerialism and performance indicators similar to those in business became important

Thus, change had begun to occur separately from the incursion of HRM, and the influences on academic industrial relations came from the sometimes anti-intellectual and overtly managerialist claims of HRM. However, the effect of HRM is partly obscured by the environmental features in each of the three countries studied. The response to the HRM incursions have varied between UK, USA and Australia, because of different intellectual and public policy environments and the differing attributes of industrial relations at the time HRM became most evident in each country. However these responses are still short-term responses. Barring one or two epochs, forty years in economics, sociology or other older social science discipline represents a brief era indeed, and in philosophy, no time at all. The impact of HRM needs to be investigated over a much longer term. If they were a genuine 'shock', then the nature of scholarship about the regulation, control and administration of work, employment and labour markets would alter to such a degree that 'HRM', however defined, would hold an hegemonic place in the analysis of work and employment, and the nature of academic industrial relations would be on a long term trajectory away from its original or earlier courses. Probably, at core, this would mean rejecting the capacity for both macro and micro analysis, eliminating analysis of power and competing goals, rejecting the ideological underpinnings which accept fairness as an important criterion, and eliminating the capacity for scholars to take an industrial relations approach regardless of their views. By the late 1990s industrial relations scholars were still upholding and demonstrating these singular attributes of their discipline, albeit tentatively. 


\section{5:00 PM 7/4/06 21}

- $\quad$ Boxall, P. and Dowling, P. (1990) "Human Resource Management, Employee Relations and the Industrial Relations Tradition in Australia and New Zealand", in G. Griffin (ed.) (1990) Current Research in Industrial Relations, AIRAANZ, Melbourne pp.152-68

- Chelius, J. and Dworkin, J. (eds.) (1990) Reflections on the Transformation of Industrial Relations, IMLR Press/Rutgers / Scarecrow Press, Metuchen, NJ

- $\quad$ Dabscheck, B. (1995) The Struggle for Industrial Relations, OUP Melbourne

- $\quad$ Delbridge, R., Turnbull, p. and Wilkinson, B. (1992) "Pushing Back the Frontiers: Management Control and Work Intensification under JIT/TQM Factory Regimes". New Technology, Work and Employment 7, 2 pp.97106.

- du Gay, P and Salaman, G. (1992) "The Cult[ure] of the Customer", Journal of Management Studies, September, 29, 5, pp.615-33

- Dundas, K. and Woldring, K. (eds.) (1998) Towards Real Reforms in Employment Relations: Can the Adversarial Culture Be Replaced?, Proceedings of the Fourth Annual Conference of the International Employment Relations Association, 10-13 July 1996, Southern Cross University / IERA, Lismore

- $\quad$ Dunlop, J. T. (1958) Industrial Relations System, Henry Holt, New York

- Dunlop, J. T. (1993) Industrial Relations System, Harvard Business School, Cambridge, Mass. (Revised edition with Commentary)

- Dunn, S. (1990) "Root Metaphor in the Old and New Industrial Relations", British Journal of Industrial Relations, 28, pp.1-31

- Fastenau, M. and Pullin, L. (1995) "Employment Relations: An Inclusive Paradigm", in L. Pullin, and M. Fastenau, (eds.) Employment Relations Theory and Practice: Current Research, Proceedings of the Second Annual Conference of the International Employment Relations Association, 1994, Gippsland School of Business, / IERA, Churchill, Vic. pp.203-14

- $\quad$ Foenander, O. de R. (1954) Better Employment Relations and Other Essays in Labour, The Law Book Co. Sydney

- $\quad$ Fox, C. and Teicher, J. (1994) "Victoria's Employee Relations Act: The Way of the Future?" in R. Callus and M. Schumacher, (eds.) (1994) Current Research in Industrial Relations, AIRAANZ, Sydney, pp.508-36

- Gahan, P. (1993) "The uncertainty of industrial relations reform: workplace bargaining in the international context" Australian Journal of Labour Law, December 6, 3, pp.292-297

- Gardner, M. and O'Leary, J. (1993) "The Reputation of Journals in Industrial Relations in Australia and New Zealand", AIRAANZ Review, Volume 2, pp.100-112

- Gardner, M. and Palmer, G. (1992a) "Employment Relations and the Notion of Strategy", in D. Blackmur, (ed.) Contemporary Australasian Industrial Relations Research, AIRAANZ Brisbane, pp.109-35

- Gardner, M. and Palmer, G. (1992b) Employment Relations: Industrial Relations and Human Resource Management in Australia, MacMillan South Melbourne

- Guest, D.E. (1987) "Human Resource Management and Industrial Relations", Journal of Management Studies, 24,5, pp.503-21

- Guest, D.E. (1990) "Human Resource Management and The American Dream", Journal of Management Studies, 27, 4, pp.377-97

- $\quad$ Guest, D.E. (1991) "Personnel Management: The End of Orthodoxy", British Journal of Industrial Relations, 29, 2, pp.149-75

- Haworth, N. (1989) "HRM: A Unitarist Renaissance", in M. Bray and D. Kelly, (eds.) Issues and Trends in Australasian Industrial Relations, AIRAANZ, Wollongong, pp.407-24

- Hayward, H. and Mortimer, D. (1988) Towards an integrated perspective of employee relations, Working Paper 1/88 Centre for Employment Relations, University of Western Sydney, Nepean

- Heneman, H. G. (1969) "Towards a General Theory of Industrial Relations" in Somers, G. (ed.) (1969) Essays in Industrial Relations Theory Iowa State, Ames, Iowa, pp.2-25

- $\quad$ Hilmer, F.G., Angwin, M., Layt, J., Dudley, G., Barrett, P. and McLaughlin, P. (1993) Working relations: A fresh start for Australian enterprises, BCA and The Business Library, Melbourne

- Hilmer, F.G., McLaughlin, P., MacFarlane, D. and Rose, J. (1989) Enterprise based bargaining Units: A better way of working, BCA, Melbourne

- $\quad$ Hilmer, F.G., McLaughlin, P., Macfarlane, D. and Rose, J. (1991) Avoiding Industrial Action: A better way of working, BCA and Allen \& Unwin, Sydney

- Howard, W. A. (1990) "Industrial Relations and Human Resource Management: Different or Differentiated Products?", in G. Griffin, (ed.) Current Research in Industrial Relations, AIRAANZ Melbourne, pp.192-200

- Hyman, R. (1994) "Theory and Industrial Relations", British Journal of Industrial Relations, 32, 2, pp.16475

- Hyman, R. (1995a) "The Historical Evolution of British Industrial Relations", in P. K. Edwards, (ed.) Industrial Relations: Theory and Practice in Britain, Blackwell Business, Oxford, pp.27-49 


\section{5:00 PM 7/4/06 22}

- $\quad$ Hyman, R. (1995b) "Editorial", European Journal of Industrial Relations, 1, 1, pp.9-16

- Hyman, R. and Brough, I, (1975); Social Values in Industrial Relations: A Study of Fairness and Equality, Basil Blackwell, Oxford

- Hyman, R. and Ferner, A. (eds.) (1994) New Frontiers in European Industrial Relations, Blackwell, Oxford

- $\quad$ Isaac, J. E. (1985) "Directions for Research", in P. Sutcliffe, and D. Ralston, (eds) Trends in Australasian Industrial Relations, AIRAANZ, Brisbane, 1985, pp.326-331

- Junor, A., Barlow, K and Patterson, M., (1994) Flexibility and Service Sector Productivity: Issues Raised by a Study of Part-Time Finance Sector Employment, in R. Callus, and M. Schumacher, (eds.)Current Research in Industrial Relations, AIRAANZ, Sydney pp.754-80

- Karmel, P. (1990) "Reflections on a Revolution: Australian Higher Education in 1989", in I. Moses, (ed.) Higher Education in the Late Twentieth Century : Reflections on a Changing System, HERDSA, Kensington, pp.24-47

- Karpin Report - Industry Taskforce on Leadership and Managerial Skills (1995) Enterprising Nation: Renewing Australia's Managers to Meet the Challenges of the Asia Pacific Century, Research Report, Volumes 1 and 2, AGPS, Canberra

- $\quad$ Kaufman, B. (1992) "Strategic Choices Facing IR and IRRA", Proceedings of Forty Fourth Annual Meeting, Industrial Relations Research Association, January, New Orleans, pp.263-72

- Kaufman, B. E. (1993) The Origins and Evolution of the Field of Industrial Relations in the United States, ILR Press, Ithaca

- Kaufman, B. E. (ed.) (1988) How Labor Markets work: Reflections on Theory and Practices by John Dunlop, Clark Kerr, Richard Lester, and Lloyd Reynolds, Lexington, Lexington Mass.

- Kaufman, B. E. (2001) "Human Resource Management and Industrial Relations: Commonalities and Differences", HRM Review, 11, 4, Winter, pp.339-74

- Keenoy, T and Anthony, P. (1992) "HRM: Meaning Metaphor and Morality" in P. Blyton and P. Turnbull, (eds.) Reassessing Human Resource Management, Sage, London, pp.233-55

- $\quad$ Keenoy, T. (1990) "HRM: Rhetoric, Reality and Contradiction", International Journal of Human Resource Management, 1, 3, pp.363-84

- Keenoy, T. (1991) "The Roots of Metaphor in the Old and the New Industrial Relations", British Journal of Industrial Relations, 29, 2, June, pp.313-38

- Keenoy, T. (1997) "HRMism and the Language of Re-Presentation: Review Article", Journal of Management, 34, 5 pp.825-44

- $\quad$ Kelly D. (ed.) (1999) Researching Industrial Relations, Federation Press, Sydney, (2nd edition)

- Kelly, D and Underhill, E. (1995) "Australian Steel: A Corporatist Transformation?" in Sonder, L. (ed.) Current Research in Industrial Relations, AIRAANZ, Melbourne, pp.238-52

- Kelly, R. (1995) "Total Quality Management: Industrial Democracy or Another Form of Managerial Control", Labour and Industry, 6, 2, March, pp.119-40

- Kerr, C. (1994) "Hicks, Douglas, and Other Predecessors", in C. Kerr and L. Staudohar, (eds.) Labor Economics and Industrial Relations: Markets and Institutions, Wertheim Publications in Industrial Relations, Harvard University Press, Cambridge, Mass. pp.66-108

- $\quad$ Kitay, J and Sutcliffe, P. (1989) "Employers and Employment Relations in Small Business in Australia", in M. Bray and D. Kelly, (eds.) Issues and Trends in Australasian Industrial Relations, AIRAANZ, Wollongong, pp.375-406

- $\quad$ Kitay, J. and Lansbury, R. D. (eds.) (1997) Changing Employment Relations in Australia, Oxford University Press, Melbourne

- Kochan, T. and Barocci, T. (1985) Human Resource Management and Industrial Relations, Scott Foresman, Glenview, Ill.

- Kochan, T. and Piore, M. (1990) Proposal for Comparative Research on Industrial Relations and Human Resource Policy and Practice, mimeo

- Kochan, T. et al. (1986) The Transformation of American Industrial Relations, Basic Books, NY

- Kochan, T. et al. (1991) "Strategic Choice and Industrial Relations Theory: An Elaboration", in H. Katz, (ed.) The Future of Industrial Relations, Cornell University, Ithaca NY

- $\quad$ Kochan, T., and Osterman, P. (1994) The Mutual Gains Enterprise, MIT Press, Cambridge Mass.

- Kochan, T., McKersie, R and Cappelli, P. (1984) "Strategic Choice and Industrial Relations Theory", Industrial Relations, 23, pp.16-38

- $\quad$ Laffer, K. (1968) "Industrial Relations: Its Teaching and Scope: An Australian Perspective" IILS Bulletin, 5, November

- $\quad$ Laffer, K. (1971) "Does compulsory arbitration prevent strikes? - The Australian Experience", Paper read at Industrial Research Unit., Wharton School, University of Pennsylvania, Philadelphia, 18 November (mimeo) 


\section{5:00 PM 7/4/06 23}

- $\quad$ Laffer, K. (1974) "Is Industrial relations an Academic Discipline?", Journal of Industrial Relations, 16, March, pp.62-73

- Lansbury, R. (1978) "Industrial Relations in the Post-Dunlop Era: An Australian View of Teaching and Research in the United States", in D. Turkington (ed.) Industrial Relations Teaching and Research: Proceedings, Industrial Relations Centre, Victoria University of Wellington, Wellington (NZ), pp.66-75

- Lansbury, R. and MacDonald, D. (eds.) (1992) Workplace Industrial Relations: Australian Case Studies, OUP, Melbourne

- $\quad$ Lansbury, R. and Spillane R. (1983) Organizational Behaviour: The Australian Context, Longman Cheshire, Melbourne

- Lansbury, R., and Bamber, G., (1995) "Making Cars in Australia: New Models of Work Production?", in L. Sonder, (ed.) Current Research in Industrial Relations, AIRAANZ, Melbourne, pp.253-261

- $\quad$ Leece, P. (1995) "Employment Relations: Implications for Teaching of Performance Appraisal", in L. Pullin, and M. Fastenau, (eds.) Employment Relations Theory and Practice: Current Research, Proceedings of the Second Annual Conference of the International Employment Relations Association, 1994, Gippsland School of Business, / IERA, Churchill, Vic., pp.291-306

- Legge, K. (1991) "HRM: A Critical Analysis", in J. Storey (ed.) New Perspectives on Human Resource Management, Routledge, London, pp.19-40

- $\quad$ Legge, K. (1995) Human Resource Management: Rhetorics and Realities, Macmillan Basingstoke

- Lewin, D., Mitchell, O. and Sherer, P. (1992) "Research Frontiers in Industrial Relations and Human Resources: A Preview of the 1992 IRRA Research Volume", in Proceedings of the Forty Fourth Annual Meeting Industrial Relations Research Association, New Orleans, January, pp.601-20

- $\quad$ Littler, C. (1987) "Labour Process Literature - A Review, 1974-1986", in K. Hince, and A. Williams, (eds.) Contemporary Industrial Relations in Australia and New Zealand: Literature Surveys, AIRAANZ, Wellington, Vol 1, pp.57-100

- $\quad$ Marginson, P. et al. (1988) Beyond the workplace: managing industrial relations in the multi-establishment enterprise, Blackwell, Oxford, UK

- McGrath-Champ, S, (1995) Employment Relations and Enterprise Bargaining - Emerging Patterns in the Coal and Construction Industries, in Sonder, L., (ed.) (1995) Current Research in Industrial Relations, AIRAANZ, Melbourne, pp.284-97

- McKersie, R. (1990) "Governance: Our Framework for Our Field", in Proceedings of Forty Third Annual Meeting, Industrial Relations Research Association, January, Washington, D. C. pp.1-10

- Meltz, N. (1992) "The IRRA as a Professional Association", Proceedings of the Forty Fourth Annual Meeting, Industrial Relations Research Association, January, New Orleans, pp.244-58

- $\quad$ Mortimer, D. and Leece, P. (eds.) (1994a) Employment Relations: Theory and Practice, Volume 1, Policy and Labour Market Studies, Proceedings of the Inaugural Conference of the International Employment Relations Association, UWS Nepean, Sydney

- $\quad$ Mortimer, D. and Leece, P. (eds.) (1994b) Employment Relations: Theory and Practice, Volume 2, Regional Studies and Case Studies, Proceedings of the Inaugural Conference of the International Employment Relations Association, UWS Nepean, Sydney

- $\quad$ Mortimer, D. and Leece, P. (eds.) (1994c) Employment Relations: Theory and Practice, Volume 3, New Directions in Human Resource Management, Proceedings of the Inaugural Conference of the International Employment Relations Association, UWS Nepean, Sydney

- $\quad$ Mortimer, D. and Leece, P. (eds.) (1995) Workplace Reform and Enterprise Bargaining: Issues, Cases and Trends, Centre for Employment Relations, UWS, Nepean, Kingswood, NSW

- $\quad$ Murakami, T. (1995) "Teamwork and Participation in the German Car Industry", in L. Sonder, (ed.) Current Research in Industrial Relations, AIRAANZ, Melbourne, pp.311-314

- Niland, J. (1981) "Research and Reform in Industrial Relations", Journal of Industrial Relations, 23, 4, December, pp.482-503

- Niland, J. (1981) "Research and Reform in Industrial Relations", Journal of Industrial Relations, 23, 4, December, pp.482-503

- Niland, J. (1984) "Industrial Relations reform: why, how and with what objective?, in J.Aldred (ed.) Industrial Confrontation, George Allen and Unwin, Sydney, pp.1-19

- Niland, J. and Prothero, M. (1976) "Industrial Relations Research in Australia", Journal of Industrial Relations, 18, 3, September, pp.272-82

- $\quad$ Nyland, C., and Svensen, S. (1994) "The Industrial Relations Court, the Crimes Act and the Right to Picket in New South Wales", in R. Callus and M. Schumacher (eds.) Current Research in Industrial Relations, AIRAANZ, Sydney pp.971-1002

- Palmer, G. (1990) "Presidential Address, Challenge and Opportunity for Industrial Relations: A Personal View", in G. Griffin, (ed.) Current Research in Industrial Relations, AIRAANZ Melbourne, pp.1-8 


\section{5:00 PM 7/4/06 24}

- Plowman, D. (1989), "Presidential Address, Industrial Relations Teaching and Research: Trends, Pressures, Strategies", in M. Bray and D. Kelly, (eds.) Issues and Trends in Australasian Industrial Relations, AIRAANZ, Wollongong, pp.1-12

- Pullin, L. and Fastenau, M. (eds.) (1995) Employment Relations Theory and Practice: Current Research, Proceedings of the Second Annual Conference of the International Employment Relations Association, 19994, Gippsland School of Business, / IERA, Churchill, Vic.

- Rosser, D., (1992) "Biting the Bullet: TQM and the Individual Experience of Organisational Change", Blackmur, D. (ed.) (1992) Contemporary Australasian Industrial Relations Research, AIRAANZ Brisbane, pp.510-18

- $\quad$ Rosser, D., Todd, P., and Fells, R. (1995) "Implementation of the Employment Relations Aspects of the Best Practice Programme: A Case Study Approach", in L. Sonder, (ed.) Current Research in Industrial Relations, AIRAANZ, Melbourne, pp.396-407

- Sewell, G. and Wilkinson, B. (1992) 'Empowerment or Emasculation? Shopfloor Surveillance in a Total Quality Organization', in P. Blyton, and P. Turnbull, (eds.) Reassessing Human Resource Management, Sage, London pp.97-115

- Sloan, J. (1994) "Comments on "The New Industrial Relations: Does it Exist?"“ in I Hunt and C. Provis, (eds.) The New Industrial Relations in Australia, Federation Press, Sydney, pp.89-91

- $\quad$ Stern, J. L. (1992) "Whither or Wither IRRA", Proceedings of Forty Fourth Annual Meeting, Industrial Relations Research Association, January, New Orleans, pp.1-8

- Storey, J. (1992) Developments in the management of human resources: an analytical review, Blackwell, Oxford

- $\quad$ Sutcliffe, P. and Sappey R. (1990) "Human Resource Management and Industrial Relations: Towards a Framework for Analysis", in G. Griffin, (ed.) Current Research in Industrial Relations, AIRAANZ Melbourne, pp.1-8

- Taylor, V. (1989) "Product Markets, Industrial Relations and the Contested Terrain", in M. Bray and D. Kelly, (eds.) Issues and Trends in Australasian Industrial Relations, AIRAANZ, Wollongong, pp.213-227

- $\quad$ Taylor, V. (1990) "Industrial Relations and Management Education", in G. Griffin, (ed.) Current Research in Industrial Relations, AIRAANZ Melbourne, pp.526 48

- Torrington D. (1989) "Human Resource Management and the Personnel Function", in J Storey (ed.) New Perspectives on Human Resource Management, Routledge, London

- $\quad$ Torrington, D. Mackay, I and Hall, L. (1985) "The Changing Nature of Personnel Management", Employee Relations, 7, 5, pp.231-43

\footnotetext{
${ }^{1}$ See e.g. Haworth 1989; Plowman, 1989

2 Previously AIRAANZ Conferences had been biennial. Partly in response to increasing numbers, the decision had been taken at Wollongong to explore the holding of conferences in a shorter time frame, and also consider a different time of year.. After Melbourne 1990, the next AIRAANZ Conference was held 18 months later on the Gold Coast in January 1992. (see Blackmur, 1992) Thereafter, conferences were held annually, but always with multiple streams except keynote speakers and Presidential Address. The Association then was also reflecting the changing context.

${ }^{3}$ Unpacking the multiple definitions of the term 'discipline' can lead to fruitless semantics. This is not to reject the historical significance and substance of the term, but in the postwar era, shifting linguistic conventions and the changing nature of research and universities render the original exact term "discipline" an anachronism. In this paper, the terms discipline and field of study have generally been used interchangeably.

${ }^{4}$ The IRRA is organised separately at Local Chapter and National levels, and is similar to the Industrial Relations Society in Australia, rather than the association of Academic Industrial Relations (AIRAANZ). At the Local Chapter level of IRRA less than 10\% of members were academics in 1990, although $30 \%$ of the National IRRA were academics. See also Stern, 1992

${ }^{5}$ Curiously, in Australia, similar charges of adversarialism were laid on the 'unique' industrial relations system, and business ideologues promoted the American model of collective bargaining as a remedy!

${ }^{6}$ Kaufman's assertions bore a curious resemblance to the BCA $(1991,1993)$ publications and to the assertions of Australian 'dry' economist, Judith Sloan. (Sloan, 1994).

${ }^{7}$ In this respect it is noteworthy that many of the critical management scholars had been industrial relations scholars who had received some higher education in sociology and who had previously published in "old"
} 
industrial relations. The greater of role of sociology for British scholarship has been noted previously. (Kelly, 1999)

${ }^{8}$ For example, US surveys of prestigious journals in labour economics and industrial relations almost always listed BJIR as an "A" journal, or a "top 5" journal. see e.g. IRRA Proceedings, 1987; See also Gardner and O'Leary, 1993 for an Australian assessment.

${ }^{9}$ In part, the increasing importance of Europe aided the continuing role for industrial relations research and teaching, as was evident in the anthologies such as Hyman and Ferner, 1994, and the appearance of the European Journal of Industrial Relations in 1995. See e.g. Hyman 1995b

${ }^{10}$ Dabscheck's (1995) The Struggle for Industrial Relations deals primarily with the public industrial relations system; and the strategies from the late 1980s to change the system, and is a notable example of the unidisciplinary 'mainstream'.

11 See e.g. Belanger et al. 1994; Appelbaum et al., 1998; Hyman and Ferner, 1994; and in Australia, Murakami, 1995, Lansbury and MacDonald, 1993

${ }^{12}$ In the same year Gardner and Palmer a widely used textbook which developed extensively on these ideas. (Gardner and Palmer, 1992b) See below

13 There have been continuing doubts about the capacity of strategic choice theory to explain actors' decisions, (Littler, 1987; Gahan, 1993) It is perhaps better designated an hypothesis.

${ }^{14}$ As will be discussed below, the term employment relations is itself a linguistic catacombs with multiple identities. By the mid-1990s it was used by both scholars who looked to the $H R M+I R$ focus as well as those on the Broad IR trajectory. The term has a long history, but is has been a label reflecting many perspectives. Thus in general I have used added descriptors to identify which "employment relations' is meant. See e.g. Foenander, 1954 and Heneman, 1969.

${ }^{15}$ See e.g. Baird, 1994; McGrath Champ, 1995; Leece, 1995 for papers presented at both AIRAANZ and IERA conferences

16 Kaufman 2001 argues that the changes were occurring earlier. However, some of the earlier shifts in academic IR reflected more the centrality of economics as a role model in US academic industrial relations. Much of economics had been permeated or captured by business values by the $1980 \mathrm{~s}$. 